\title{
Short-chain sphingolipids for enhanced cellular uptake of liposome-encapsulated amphiphilic anti-cancer drugs
}

\author{
Lília RC Pedrosa ${ }^{1 *}$, Albert van Hell ${ }^{2}$, Wim van Blitterswijk², Ann LB Seynhaeve ${ }^{1}$, Alexander MM Eggermont ${ }^{1}$, \\ Timo LM ten Hagen', Marcel Verheij ${ }^{2,3}$, Gerben A Koning ${ }^{1}$
}

From 16th International Charles Heidelberger Symposium on Cancer Research

Coimbra, Portugal. 26-28 September 2010

Short-chain sphingolipids, such as $\mathrm{C}_{8}$-Glucosylceramide $\left(\mathrm{C}_{8}\right.$-GC) have been described to enhance the cellular uptake of amphiphilic drugs, in free form or when coformulated in liposomes $(1,2)$. The involved mechanism is currently unknown, but is hypothesized to induce domain or pore formation in the plasma membrane (3). The aim of this study is to further explore this specific drug uptake process by $\mathrm{C}_{8}$ - $\mathrm{GC}$ to enhance intracellular delivery of liposomal doxorubicin.

Liposomes, containing different percentages of incorporated $\mathrm{C}_{8}$-GC were prepared and loaded with doxorubicin. Characterization was performed by measuring size, polydispersity index (pdi), phospholipid and doxorubicin content. In vitro anti-tumor activity was studied towards a panel of human tumor cell lines and normal cells: endothelial cells and fibroblasts.

Doxorubicin liposomes (Dox-L) enriched with $10 \mathrm{~mol} \%$ $\mathrm{C}_{8}$-GC presented less fluctuation in size and pdi than 15 $\mathrm{mol} \%$ and efficiently retained their contents under culture conditions (10\% serum). In all tumor cell lines tested $\mathrm{C}_{8}$ GC-Dox-L exerted increased cytotoxicity, resulting in up to 20 fold lower $\mathrm{IC}_{50}$ values compared to standard Dox-L. This effect was not observed with endothelial cells and with fibroblasts it was much less pronounced.

In conclusion, 10 mol\% $\mathrm{C}_{8}$-GC-enriched Dox-L had optimal stability and showed enhanced cytotoxicity towards tumor cells and not towards normal cells. Based on these findings, modification of Dox-L

\footnotetext{
* Correspondence: I.cordeiropedrosa@erasmusmc.nl

'Laboratory Experimental Surgical Oncology, Section Surgical Oncology, Department of Surgery, Erasmus MC- Daniel den Hoed Cancer Center, Rotterdam, The Netherlands

Full list of author information is available at the end of the article
}

formulations with $10 \mathrm{~mol} \%$ of $\mathrm{C}_{8}-\mathrm{GC}$ can be used to improve drug delivery to tumor cells.

\section{Author details}

'Laboratory Experimental Surgical Oncology, Section Surgical Oncology, Department of Surgery, Erasmus MC- Daniel den Hoed Cancer Center, Rotterdam, The Netherlands. ${ }^{2}$ Division of Cellular Biochemistry, The Netherlands Cancer Institute, Amsterdam, The Netherlands. ${ }^{3}$ Department of Radiotherapy,

The Netherlands Cancer Institute, Amsterdam, The Netherlands.

Published: 24 September 2010

\section{References}

1. Veldman RJ, Zerp S, van Blitterswijk WJ, Verheij M: N-hexanoylsphingomyelin potentiates in vitro doxorubicin cytotoxicity by enhancing its cellular influx. Br J Cancer 2004, 90:917-925.

2. Veldman RJ, Koning GA, van Hell A, Zerp S, Vink SR, Storm G, Verheij M, van Blitterswijk WJ: Coformulated N-octanoyl-glucosylceramide improves cellular delivery and cytotoxicity of liposomal doxorubicin. J Pharmacol Exp Ther 2005, 315:704-710.

3. Siskind L: Mitochondrial ceramide and the induction of apoptosis. J Bioenerg Biomembr 2005, 37:143-153.

doi:10.1038/sj.bjc.6601581

Cite this article as: Pedrosa et al:: Short-chain sphingolipids for enhanced cellular uptake of liposome-encapsulated amphiphilic anticancer drugs. BMC Proceedings 2010 4(Suppl 2):P39.

Submit your next manuscript to BioMed Central and take full advantage of:

- Convenient online submission

- Thorough peer review

- No space constraints or color figure charges

- Immediate publication on acceptance

- Inclusion in PubIMed, CAS, Scopus and Google Scholar

- Research which is freely available for redistribution 